\title{
Gite $R_{C}$ Coastal Engineering Research Center
}

\section{Marine Biological Laboratory \\ LIBRARY \\ MAR 311965 \\ WOODS HOLE, MASS.}

\section{BEACH CHANGES AT VIRGINIA BEACH, VIRGINIA}

MISCELLANEOUS PAPER No. 6-64 NOVEMBER 1964

GB

450

.43

$n 0.6-64$

DEPARTMENT OF THE ARMY CORPS OF ENGINEERS 


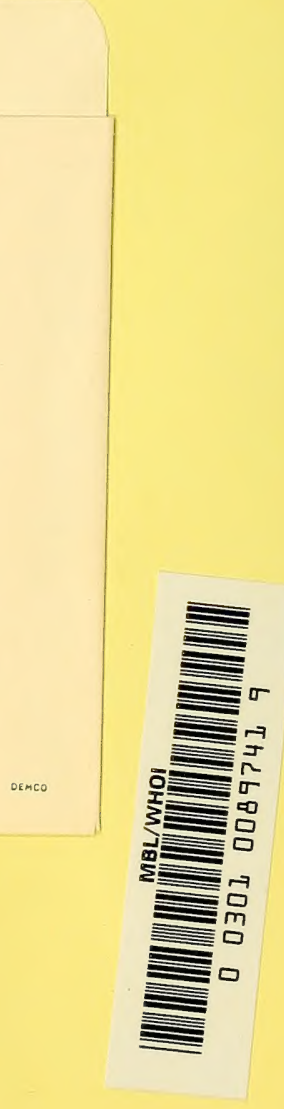


FOREWORD

Precision measurements of changes in the morphology of a given beach can be of great value to engineers and others engaged in the design of structures to be emplaced on or near the strand and to those concerned with beach protective or beach nourishment measures. This present study of changes in beach profiles and topography of the nearshore bottom at Virginia Beach was undertaken because of the magnitude of the investment of private and commercial resort property there, because of the artificial beach nourishment project in operation there since 1955, because of plans for the development of Rudee Inlet, and because of plans for the possible installation of of a submarine sewage outfall system.

This study is not intended to present a definitive analysis relating wave action to adjustments in the shore profile at Virginia Beach. Rather it serves to show the magnitude of beach profile variations that may be expected over (1) a period of years; (2) seasona11y; and (3) in one case, for a single violent storm. The reader is referred to Beach Erosion Board Technica 1 Memoranda Nos. 55 and 57 for a statistical summary of the wave action that can be expected in deep water off Virginia Beach during an "average" year.

This report was prepared by Dr. Wyman Harrison, Associate Marine Scientist of the Virginia Institute of Marine Science, in pursuance of Contract DA-49-055-CIV-ENG-63-6 with the Beach Erosion Board, and in collaboration with Dr. Kenneth Wagner, formerly Head of the Department of Biology at the Norfolk College of William and Mary, who supervised the field work at 6lst Street.

This report is published under authority of Public Law 166, 79th Congress, approved 31 July 1945, as modified by Public Law 88, 172, approved 7 November, 1963. 
Page

ABSTRACT

।

INTRODUCT ION

PREVIOUS WORK

2

High Water Shoreline Changes

3

FIELD MEASUREMENTS

4

61st Street Transect

15 th and 3 rd Street Pier Transects

Camp Pendleton Transect

Soundings off Camp Pendleton

4

4

5

5

RESULTS AND INTERPRETATIONS

6

Profile Modifications

6

Longshore Bars and Troughs

7

Cut-and-Fil1 of Nearshore Bottom

9

9

CONCLUDING REMARKS

9

Genesis of Beach Changes

9

Engineering Implications

10

ACKNOWLEDGMENTS

REFERENCES

12

LIST OF FIGURES 
U. S. Coast and Geodetic Survey, Norfolk, Virginia (1), and Virginia Institute of Marine Science, Gloucester Point, Virginia

and

Kenneth A. Wagner

Powe 11 Laboratories, G1adstone, Oregon(2)

\section{ABSTRACT}

This descriptive report summarizes the results of repeated profiles taken daily, weekly, or (rarely) monthly along four transects. Seven topographic maps of the nearshore bottom, based on detailed soundings to depths of 15-24 feet below MLW off Camp Pendleton, are also presented. One of the profiles and one of the maps show the effects of waves from the violent storm of 7-8 March 1962.

Week1y and month1y observations at 61st Street, repeated for a continuous 23-month period, showed that the greatest vertical changes of the foreshore profile amounted to 6.6 feet. This maximum variation was centered in the vertical zone on the foreshore coinciding with the interval between mean tide leve 1 and mean high water. An unknown amount of change in altitude along the profile, for about 17 months, is believed to be related to artificial beach nourishment in progress nearby at the time the profiles were run. Minor changes were noted in weekly profiles across the dune at 61st Street from November 1956 - June 1957 , the greatest horizontal change ( 2.8 feet) occurring near the dune crest on the seaward facing slope where it was stabilized by vegetation. Approximately one-half of the dune was lost during the storm of March 7-8, 1962.

Twenty-five profiles at Camp Pendleton, taken on consecutive days at low tide, yield a rhythmic pattern, when superimposed. The bottom changes could be qualitatively related to changes in the wave regime, but were not always dependent upon breaking waves for their formation or dissolution. Magnitudes of daily cut and fill of the foreshore face approximated a few tenths of a foot. The greatest daily change of the nearshore bottom, 2.5 feet, occurred 225 feet from the MLW shoreline.

\footnotetext{
(1) Present address: Land \& Sea Interaction Laboratory, 439 York St., Norfolk, Virginia. Study completed while at the Virginia Institute of Marine Science.

(2)

Formerly at the Norfolk College of William and Mary
} 
Three of the seven maps of the nearshore bottom exhibit undulations that are 1 ike $1 \mathrm{y}$ correlative with the longshore bar and trough "rhythms" described from Japanese coastal waters by Hom-ma and Sonu (1963). The maps show arcuate bar units whose feet correspond to shoal areas and apices to troughs. The significance of bar-trough rhythms to coastal engineering is stressed, their importance to expectable ranges of cut-andfill being considerable. Maximum ranges of cut-and-fill noted at points out from the MLW shoreline at Camp Pendleton for months from April through October (during normal weather) are: 50 yards - 6 feet; 100 yards - 8 feet; 200 yards - 9 feet; and 300 yards - 12 feet. An increase in the range at the 50-yard point, from 6 to 8 feet, is required if the March 7, 1962 storm topography is considered.

\section{INTRODUCT ION}

Engineers, contractors, business men, homeowners, and others engaged in working or living by the sea have need of accurate information on the expectable variation in morphology of the particular beaches with which they are involved. This study presents some accurate data on the character and magnitude of changes in beach morphology for a portion of the Atlantic coast of the City of Virginia Beach (Figure 1). Data are presented for both "average" weather changes and for those induced by the great storm of 7-8 March 1962 .

The term "beach" is used in this study in the broad sense, encompassing here the general zones of backshore, beach ridge (and associated dunes), foreshore, and nearshore bottom (in this study out to water depths up to 25 feet below MLW).

\section{PREVIOUS WORK}

Among the many important studies in the general field of descriptive work on beach changes are those of Shepard (1950), Inman (1953), Bruun (1954a, 1954b), Inman and Rusnak (1956), and Zeigler and Tuttle (1961). King (1959) has a comprehensive review of beach changes in her recent book, "Beaches and Coasts."

Two studies have been published that mention beach changes at Virginia Beach (Figure 1). The "Beach Erosion Control Study" of the U. S. Army Corps of Engineers (U. S. Congress, 1953) indicated: 
The shoreline is susceptible to greater changes as a result of a major storm or a series of severe winter storms than would occur norma $11 y$ in a period of 15 to 20 years. Investigations have further disclosed that in a number of instances where surveys have indicated a considerable change in the high-water shoreline, the volumetric change was almost negligible. Certain types of storms tend to tear down the beach and move the material slightly offshore, whereas subsequent fair weather moves the sand back to the beach and general1y restores the original berm (1953, p. 12).

Duplicate profiles taken along several transects in June 1933 and September 1946 were cited as evidence that the most extensive erosion had taken place in the vicinity of the south end of the seawal1 (Figure 1) where the backshore had been eroded to a maximum depth of 4 feet and an average depth of 2 feet, with a resultant flatter foreshore. This general condition was found to hold northward some 4,800 feet to the first angle point in the seawa11. The comparative cross sections at 20 th Street (Figure 1) disclosed a very slight erosion of the backshore with a pronounced flattening of the foreshore. Near the north end of the seawa11, both backshore and foreshore were found to have gained material. Near Avenue B (Figure 1) erosion of approximately 3 feet of the foreshore was found.

The discussion of the profiles presented in the report concludes with the statement, "It is readily apparent from these profiles that the south end of the beach, above the elevation of mean low water, has been eroded to a consideraby greater degree than other areas" $(1953$, p. 14). It should be noted, however, that the magnitudes of the changes reported are within the 1 imits of expectable winter (Figure 2) and, in some cases, summer changes in beach profiles found in the present study. More convincing evidence of shoreline changes is presented (1953, p. 12) in a table summarizing the changes in the position of the mean high water shoreline from 1931-1932 to 1944, 1944 to 1946, and 1931-1932 to 1946. Results of this last comparison are reproduced below. The shoreline position measurements (1953, p.12) show more convincingly than the profiles that the greatest erosion is at the south end of the Borough of Virginia Beach (Figure 1), while at the northern end the tendency is for progradation.

\section{High-water Shoreline Changes}

\section{Section of Beach}

Rudee Inlet to beginning of seawal1 South end of seawa11 to 20th Street 20 th Street to north end of seawal1 North end of seawa11 to old town limit Entire beach front, Rudee Inlet to north limit of old town

$$
\begin{gathered}
1931-32 \text { to } 1946 \\
\hline-80.7 \mathrm{ft} . \\
-55.3 \mathrm{ft} . \\
-23.4 \mathrm{ft} . \\
+9.0 \mathrm{ft} . \\
-29.5 \mathrm{ft} .
\end{gathered}
$$


In his report on the behavior of beach fill at Virginia Beach, Watts (1959, Figures 4A, 4B) presents twenty-five profiles in the region of those described above. Watts calculated net volume changes from repetitive profiles using the end-area method (for profiles that intersected at about the 20- to 25-foot depth). He concluded (1959, p. 5) that of some $1,563,000$ cubic yards of material placed between Rudee Inlet and 46th Street (Figure 1) during the period September 1946 - June 1952, some 1,313,000 cubic yards had been 1ost. His data indicated (1959, p. 7) that as a result of beach nourishment, the width of the beach above mean high water datum in 1958 was about equal to that of September 1946 in the study area.

Inasmuch as data were lacking on short-term beach changes in the area, the authors initiated the program of beach profiling described below.

\section{FIELD MEASUREMENTS}

\section{1st Street Transect}

A profile line (transect) was established at 61st Street (Figure 1) on 4 November 1956, after two to three weeks of predominant1y northeast winds. Strong surf action had exposed a stratum of peat and rooted cypress stumps on the foreshore by the date of this first profile. Profile measurements along the transect were made by standard leveling techniques, using a U. S. Coast and Geodetic Survey bench mark for vertical control. The transect was resurveyed each week through $8 \mathrm{March} 1958$, and then once a month until September 1958. A final survey was made after the great storm of 7-8 March 1962 .

Accuracy of the altitudinal determinations was of the order of \pm 0.05 foot, but because determinations were made at 10-foot intervals, 1oca 1 irregularities of the beach profile were obscured.

\section{5 th and 3 rd Street Pier Transects}

Control for repeated daily profiles along piers at 15 th and $3 \mathrm{rd}$ Streets was accomplished by surveying stations at 25 -foot intervals along the lengths of the piers. Level lines were carried from bench marks on land, and the altitudes of the stations were determined relative to mean sea leve1. Field assistants, using calibrated sounding lines, occupied the stations at 15 th street once each day at the time of low tide (as predicted in tide tables), and every fifth day at the 3 rd Street pier, during the period 11 June - 5 Ju1y 1963. The pier stations were also occupied on 25 March and 10 Apri1 1963. 
Precision of the sounding 1 ine measurements is estimated at \pm 0.20 foot over water and \pm 0.15 foot over land. The soundings were taken over a 1-hour period, centered on the low tide time as predicted in tide tables. Minor irregularities of the profiles (Figures 4, 5) are obscured by the relatively large interval ( 25 feet) between stations.

\section{Camp Pendleton Transect}

A profile line was established paralle1 to and one foot north of the north property line of Camp Pendleton (Figure 1), as follows. Fifteen 2-inch stee1 pipes were jetted into the bottom at 25-foot intervals for a distance of 375 feet seaward of the end pile in a 1 ine of pre-existing stee 1 fence posts and wooden piles that marked the property 1 ine. The tops of the pipes were then leveled relative to U.S.Coast and Geodetic Survey bench mark datum, as were reference stations along the fence and the pre-existing piles.

Stations along the offshore portion of the profile line were occupied by swimming from pipe to pipe. A swimmer held a calibrated pole in what he believed to be a vertical position, read the pole at the pipe top, and recorded the value on a plastic disk secured to his neck by a cord. This procedure was followed during the period 10 June - 5 July 1963 . Surveys along this line during March and April were made from a DUKW. The accuracy of the determinations was of the order of \pm 0.2 foot offshore and \pm 0.05 foot over land.

\section{Soundings Off Camp Pendleton}

In addition to the profiles to be presented for the Camp Pendleton property 1 ine, topographic maps of the nearshore bottom in the area (Figure 1) off $\mathrm{C}_{a m p}$ Pendleton over the period from May 1961 to April 1963 are a.1so presented.

The field method consisted either of fathometer surveys from rubber boats or handline soundings by swimmers. The swimmers were spaced at 75foot intervals along a taut line that was moved along perpendicular to shore. At intervals of 75 feet in the direction paralle1 to shore, each man took a sounding with a calibrated line. (The still water level was estimated).

Soundings were reduced to MLW datum and plotted on a map. Values upon which the contoured maps of this study are based are believed accurate to between \pm 0.5 and \pm 1.0 foot. 


\section{RESULTS AND INTERPRETATIONS}

\section{Profile Modifications}

Winter Months. An idea of the expectable wintertime profile changes in a region of essentia11y unmodified foreshore and dune at Virginia Beach is shown in Figure 2. The period of destructive winter northeaster storms, is roughly November through March. The envelope of altitudinal variations (Figure 2) at stations along the profile at 61st Street shows that the greatest winter month changes can be expected in the intertidal zone and that the beach there may fluctuate in altitude through a distance of 3 to 5 feet. This range would have been slightly greater had the silt beds (Figure 2) been missing. The silts are eroded with difficulty and, in fact, are recognized as the sediments that determine the position of the coastiine today.

These deductions about profile changes in the foreshore area of 61 st Street are based on measurements that are believed representative of the natural beach response to the existing forces over the period of study. Watts (1959, p. 3) indicates that during al1 of 1956 only 1,000 cubic yards of beach fill were placed artificially along the beach from Rudee Inlet to 42 nd Street (Figure 2). In 1957, however, 89,000 cubic yards were placed along the shore in this area, but the pumping did not exceed a few thousand cubic yards by Apri1 6, 1957.

Changes in the dune profile (Figure 2) were minor, the greatest changes coming near the dune crest on the steep seaward slope where stabilization by vegetation was absent. The remainder of the dune was only poorly stabilized.

Summer Months. The summer months, April through October, show somewhat similar changes in the envelope of altitudes at 61st Street, a1though the envelope is not presented here. Both winter and summer profile changes at five stations are plotted on Figure 3. There is a difference only in the rapidity of change as noted in qualitative observations, the more rapid changes occurring in the winter months. Summer changes in the profile envelope can be deduced from Figure 3.

Yearly. Data (Figure 3) from 23 consecutive months suggest a gradua 1 increase in the volume of foreshore sand above MLW (November 1956 - June 1958) at 61 st Street. This can very probably be related to the large amounts of sand pumped on the beach from the Owl Creek hydraulic dredge during 1957 - 1958 (Watts, 1959, p. 3). Watts notes (1959, p. 2) that available evidence indicates a northward drift of beach material in the area in the summer months. Thus, the beach at 61st Street, which was definitely downdrift from the zone of artificial nourishment in the summer months, would be expected to build up. This is borne out by the curves of Figure 3. 
Exceptional Storms. Waves of the most destructive storm to influence the strand at Virginia Beach within historic times were generated by the Ash Wednesday extratropical disturbance of 7-8 March 1962. The magnitude of profile modification at 61st Street is indicated in Figure 2, where it can be seen that about 50 percent of the dune was eroded.

Daily Changes (Summer Months). The daily changes in nearshore profiles along three transect lines are recorded in Figures 4, 5, and 6 . It should be mentioned that the inshore segments of the profiles along the fishing piers at 15 th and 3 rd Streets (Figures 4,5 ) leave something to be desired. Some buildup of sand around the large number of pilings supporting the houses on the landward ends of the piers, and the necessity of making an offset in the profile line at the landward end of the 15th Street pier, make the profiles there of possible limited application, when compared to profiles of unmodified beaches. Also, the $3 \mathrm{rd}$ street pier is in close proximity to Rudee Inlet, where special and restricted conditions occur. Pumping of sand and silt occurred also in the vicinity of both piers for a few evening hours on a few days in June and July. The effect of this last is believed to be negligible, however, as measurements indicated that the bulk of the material was silt size.

Maximum daily changes in cut-and-fill of the foreshore face at the Camp Pendleton transect (Figure 6, stations 0307-0311) were of the order of a few tenths of a foot. Maximum change in the nearshore bottom occurred at stations 318 and 319 , about 225 feet from the MLW shoreline, and amounted to 2.5 feet. This was qualitatively related to an increase in wave heights and the strongest (onshore) winds of the period. A rhythmic series of undulations is evident from the profiles of Figure 6, perhaps in part related to the bar and trough rhythms described below. Of interest is an apparent "nodal" point at station 0316.

Seasonal Changes. The profiles of Figure 6 might be interpreted as showing the expectable divergence of winter and summer profiles, the eroded winter foreshore face undergoing buildup during summer, and the winter storm bar and trough becoming more subdued toward summer. The fact is, however, that the magnitudes of the vertical trough-bottom to bar-crest distance of the winter and summer profiles can be about equal (Figure 6), depending upon when measurements are taken. Figures 4 and 5 do not show convincing differences between winter and summer profiles.

\section{Longshore Bars and Troughs}

Figures 7-13 show something of the alternating simple to complex bartrough morphology to be expected at Virginia Beach. These possible variations must be kept in mind when attempting to interpret profile data such as those of Figures 4, 5, and 6. Ratios such as those of 1ongshore bar depth to bar base (Beach Erosion Board, Technical Memorandum No. 15), for 
example, may have meaning when a single pattern prevails, but have much less significance when a more complex one prevails.

Rhythmic Patterns. Hom-ma and Sonu (1963) have made a study of rhythmic longshore bar patterns in Japanese coastal waters, relying heavily on airphoto interpretation. According to these authors (1963, p. 248), "a longshore bar may attain a rhythmic pattern consisting, of echelons of arcuate (or lunate) bar units, which in entire appearance resembles that of a honeycomb." They also have found that when a rhythmic bar system is present, it is tied in closely with various rhythms found along the littoral shore. They found (p. 255) that, in genera1, the foot of an arcuate unit corresponds to a shoal, while the center to a deep trough and a steep bottom slope in the surf zone. The rhythms were thought to have their fundamental origin in the inherent undulations of the offshore bottom. (It is not believed that artificial sand pumping had any effect on the topography shown on the maps of this study because the area is updrift of the zone of beach nourishment in summer, and nourishment was slight during the period of measurements.)

Three maps appear to display the rhythms described above. Figure 7 , for May 1961, shows by shading the bar crest patterns apparent from the detailed soundings. They have the two characteristics mentioned previously. Somewhat similar rhythms, but without the definitive troughs, are present on the map for September 1962 (Figure 12), and there is a suggestion of a much larger rhythm on the October 1961 map (Figure 8), the shoreward margin of the apex 1ying just seaward of the 15-foot depression contour.

Rates of Modification. An idea of the expectable rates and magnitudes of summer changes, at 2-month intervals, may be gained from Figures 9,10 , 11, and 12. Significant changes are seen from map to map. Of particular interest are the maps and profiles (Figure 9) made 12 days after the great storm of March 7-8, 1962. Profiles show a nearly continuous, re1atively deeply incised trough. Immediately seaward of the bar crest the bottom descends at a fairly regular rate. The steepness of the trough sides and their tendency to intersect at the bottom of the trough, suggests that the trough bar configuration rather closely duplicates that formed by the waves of the Ash Wednesday storm itse1f. Two months later (Figure 10) the trough is wider and more flat bottomed; 4 months later (Figure 11) the trough has been obliterated in places; and 6 months 1ater (Figure 12) an apparent rhythm pattern has developed, all but destroying the relatively simple pattern imparted by waves of the great storm.

Daily changes in bar and trough formation, evident from the profiles of Figure 6, are interesting because in several cases the bars occurred in depths we 11 beyond those influenced by the prevailing breaking waves. 
Studies of the detailed soundings used in the preparation of Figures $7,8,10,11,12$, and 13 revealed the following maximum ranges in a1titude of bottom level at points out from the MLW shoreline: 50 yards - 6 feet; 100 yards - 8 feet; 200 yards - 9 feet; and 300 yards - 12 feet. When Figure 9, for the March 7, 1962 storm is added in, the only range value that is changed is that for the 50-yard position, which is increased to 8 feet. Cut-and-fill incident to formation and destruction of bar rhythms seems to be a major factor in determining the magnitudes reported.

\section{CONCLUDING REMARKS}

\section{Genesis of Beach Changes}

Virtua11y nothing has been presented in this study relative to the causes of the observed beach changes. This will be presented in another study of this series by W. Harrison and W. C. Krumbein (1964). It is the authors' belief, however, that the descriptive material presented herein will aid students of beach processes, whether they be marine geologists, engineers, or interested laymen. A few observations of possible value to engineers conclude the report.

\section{Engineering Imp1ications}

The rapidity of beach changes, even under average sea-state conditions, cannot be underestimated. A beach is simply one of the most unstable of al1 landforms. The daily profiles of Figure 6 provide only minimum values for development of expectable ranges of cut-and-fil1, because they were obtained during a period of relatively low energy input for this beach. Ranges of vertical changes for the nearshore bottom are somewhat more dependable.

Design criteria must, of course, take into consideration the changes to be expected from great storms, which will be many times those of the normal sea-state conditions. It may be inferred from the 1 imited data of this study that under great storm conditions the foreshore slope and beach ridge will undergo greater change than the nearshore bottom. Figures 2 and 9 may provide some guidance as to the magnitudes of expectable changes in sand leve1 from great storms.

Undulatory longshore bar and trough rhythms bear consideration when attempting to design submerged breakwaters. Hom-ma and Sonu (1963) have noted the importance of understanding these rhythms when specifying the length of groins and jetties, while Bruun (1954a) states that sudden shoaling at a coastal inlet may be due to the migration of a large-scale rhythm. 


\section{ACKNOWLEDGMENTS}

The authors wish to acknowledge the aid in taking profile measurements of Messrs. R. Mulford, N. Petersen, R. Tuck, and G. Williamson. Professor K. Bick, College of William and Mary, plotted many of the profile data. Mr. M. Lynch and Underwater Demolition Unit Two, U. S. Navy Amphibious Base, Little Creek, Virginia, aided in obtaining the nearshore bottom maps at Camp Pendleton. The consulting-engineering firm of Langley and McDonald, Norfolk, Virginia, furnished data on the elevations of secondary bench marks. Part of the profile measurements were obtained with the aid of personne 1 from Fort Story, Virginia, U. S. Army Transportation Corps. Mr. C. Ca1dwe11, Carpenter Construction Company, and Mr. W. Midgett aided in jetting pipes into the bottom. 


\section{REFERENCES}

1. Bruun, P., Migrating Sand Waves and Sand Humps, Proc. 5th Conf. Coasta1 Eng., Council Wave Res., Berkeley, Ca1if., 1954a.

2 . Coast Erosion and the Development of Beach Profiles, Beach Erosion Board, Tech. Memo. No. 44, 1954 b.

3. Harrison, W. and W. C. Krumbein, Interactions of the Beach-OceanAtmosphere System at Virginia Beach, Virginia, Coastal Engineering Research Center, Tech. Memo. No. 7, 1964.

4. Hom-ma, M., and C. Sonu, Rhythmic Pattern of Longshore Bars Related to Sediment Characteristics, Proc. 8th Conf. Coastal Eng, Council Wave Res., Berkeley, Calif., 1963.

5. Inman, D. L., Areal and Seasonal Variations in Beach and Nearshore Sediments at La Jo1la, California, Beach Erosion Board, Tech. Memo. No. $39,1953$.

6. Inman, D. L. and G. A. Rusnak, Changes in Sand Leve 1 on the Beach and She1f at La Jo1la, California, Beach Erosion Board, Tech. Memo. No. $82,1956$.

7. King, C. A. M., Beaches and Coasts, Edward Arnold, London, 1959.

8. Shepard, Francis P., Longshore Bars and Longshore Troughs, Beach Erosion Board, Tech. Memo. No. 15, 1950.

9. Beach Cycles in Southern California, Beach Erosion Board, Tech. Memo. No. 20, 1950.

10. U. S. Congress, Virginia Beach, Virginia Beach Erosion Contro1 Study, House Doc. No. 186, 83rd Congress, 1953.

11. Watts, George M., Behavior of Beach Fill at Virginia Beach, Virginia, Beach Erosion Board, Tech. Memo. No. 113, 1959.

12. Zeigler, J. M. and S. D. Tuttle, Beach Changes Based on Daily Measurements of Four Cape Cod Beaches, Jour. Geology, v. 69, 1961, pp. 583599. 
1. Location Map.

2. Profile Changes at 61st Street Transect.

3. Variations in A1titude at Selected Stations on 61st Street Transect.

4. Profiles at 15 th Street Transect.

5. Profiles at 3 rd Street Transect.

6. Profiles at Transect Along North Property Line of Camp Pendleton.

7. Nearshore Bottom off Camp Pendleton, 22 May 1961.

8. Nearshore Bottom off Camp Pendleton, 9 October 1961.

9. Nearshore Bottom off Camp Pendleton, 20 March 1962.

10. Nearshore Bottom off Camp Pendleton, 22 May 1962.

11. Nearshore Bottom off Camp Pendleton, 2 Ju1y 1962.

12. Nearshore Bottom off Camp Pendleton, 25 September 1962.

13. Nearshore Bottom off Camp Pendleton, 22 April 1963. 


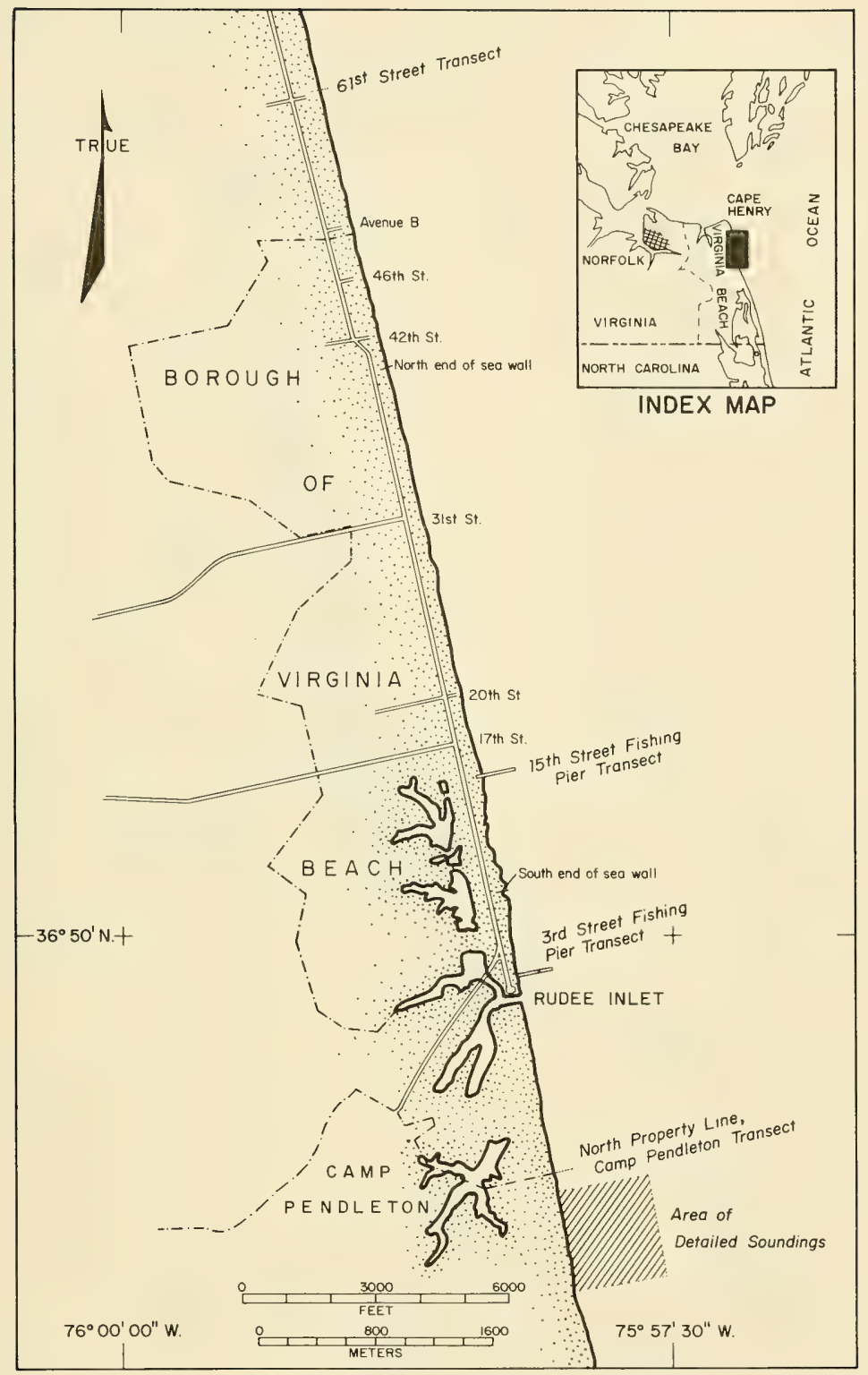

FIGURE 1. LOCATION MAP. 


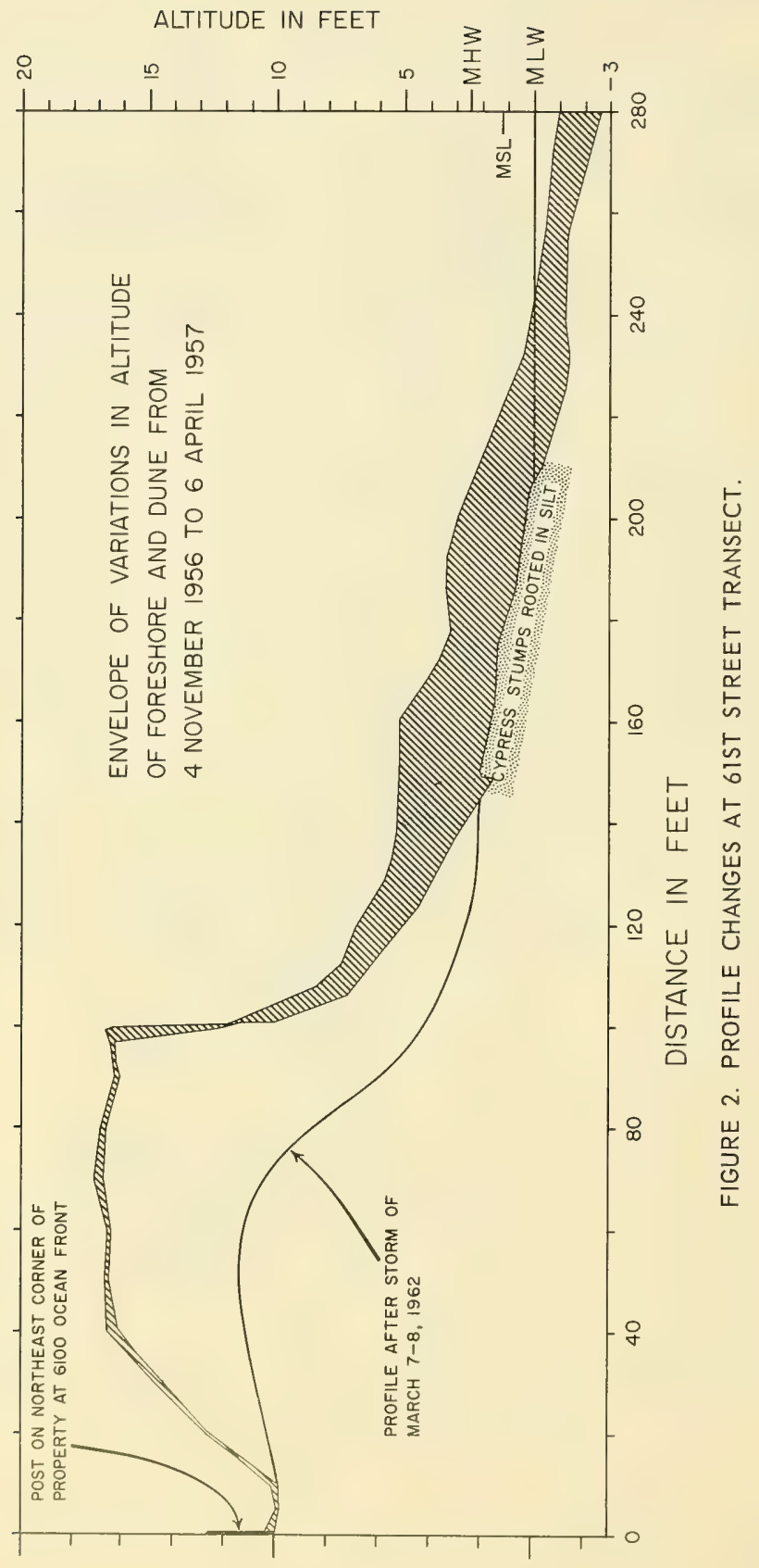




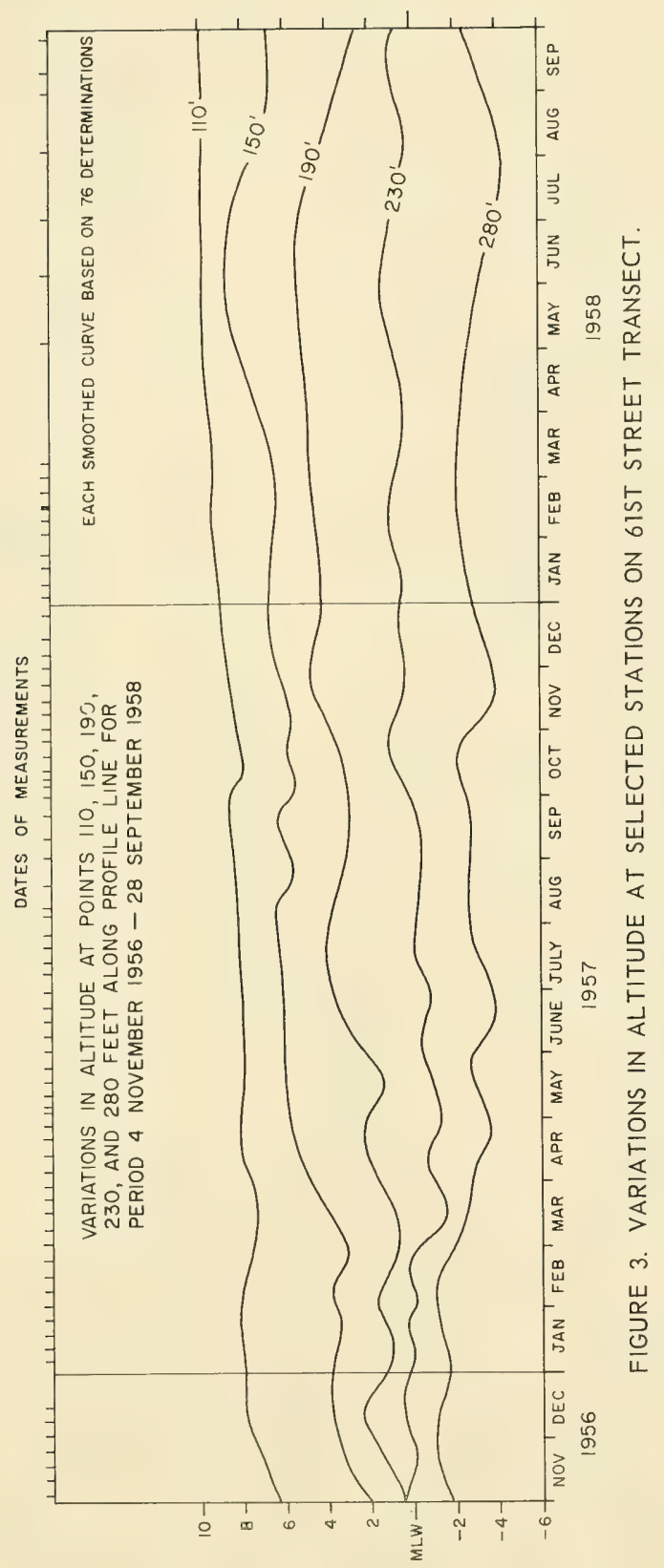

$\perp \exists \exists \unlhd$ NI $\exists 0 n \perp 117 \nabla$ 


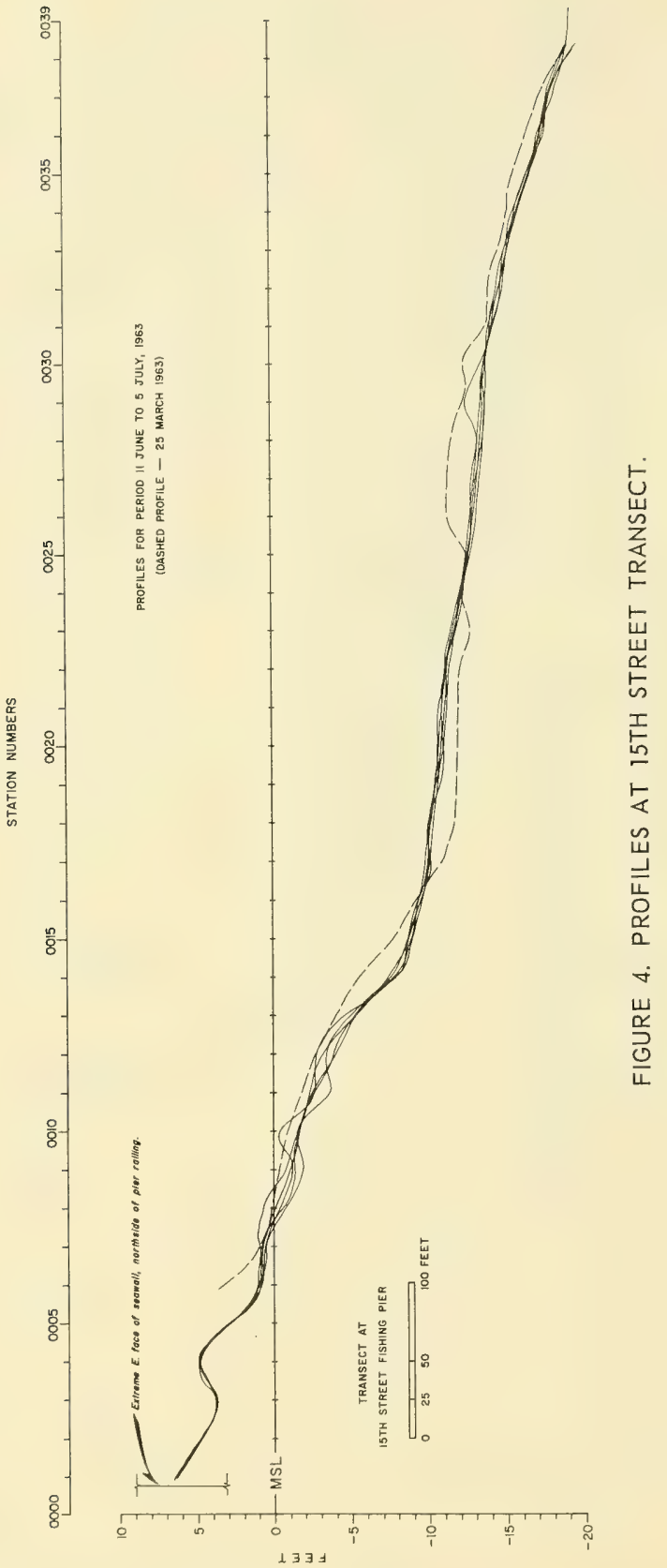




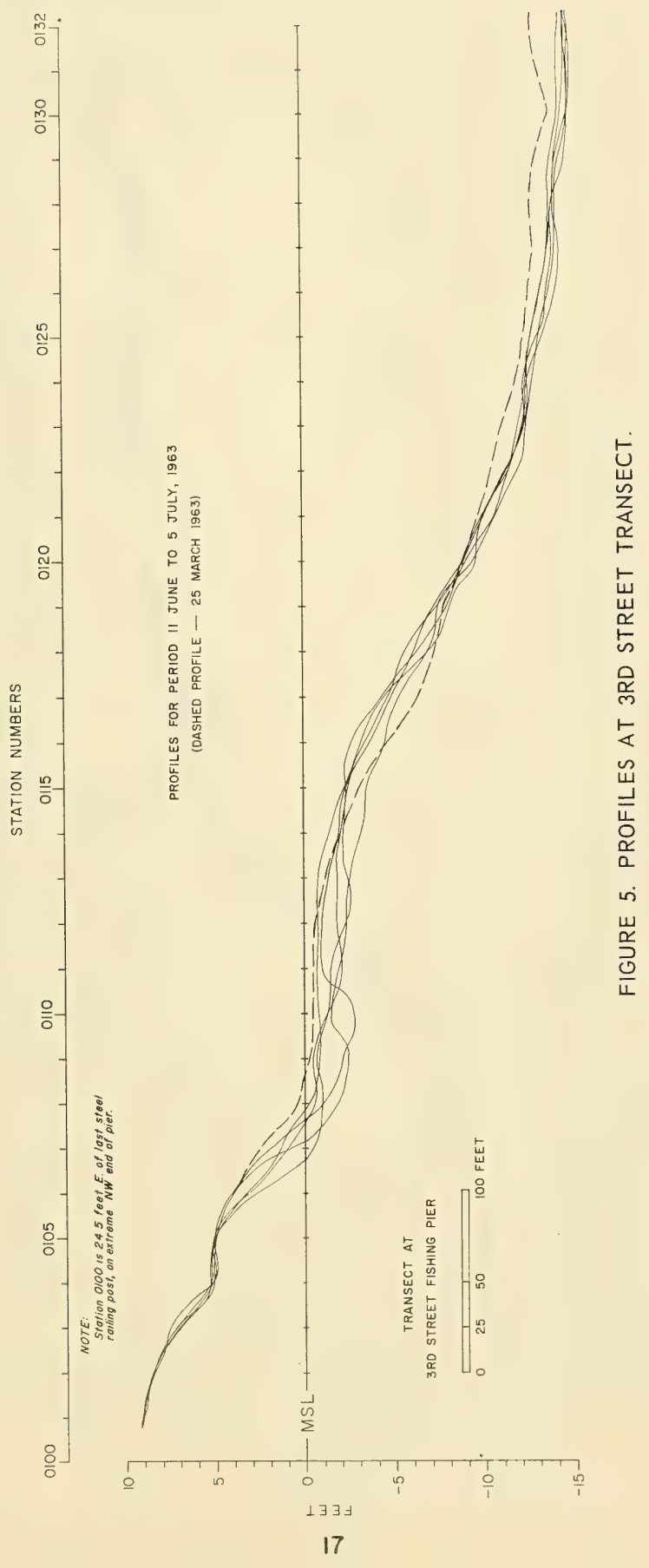




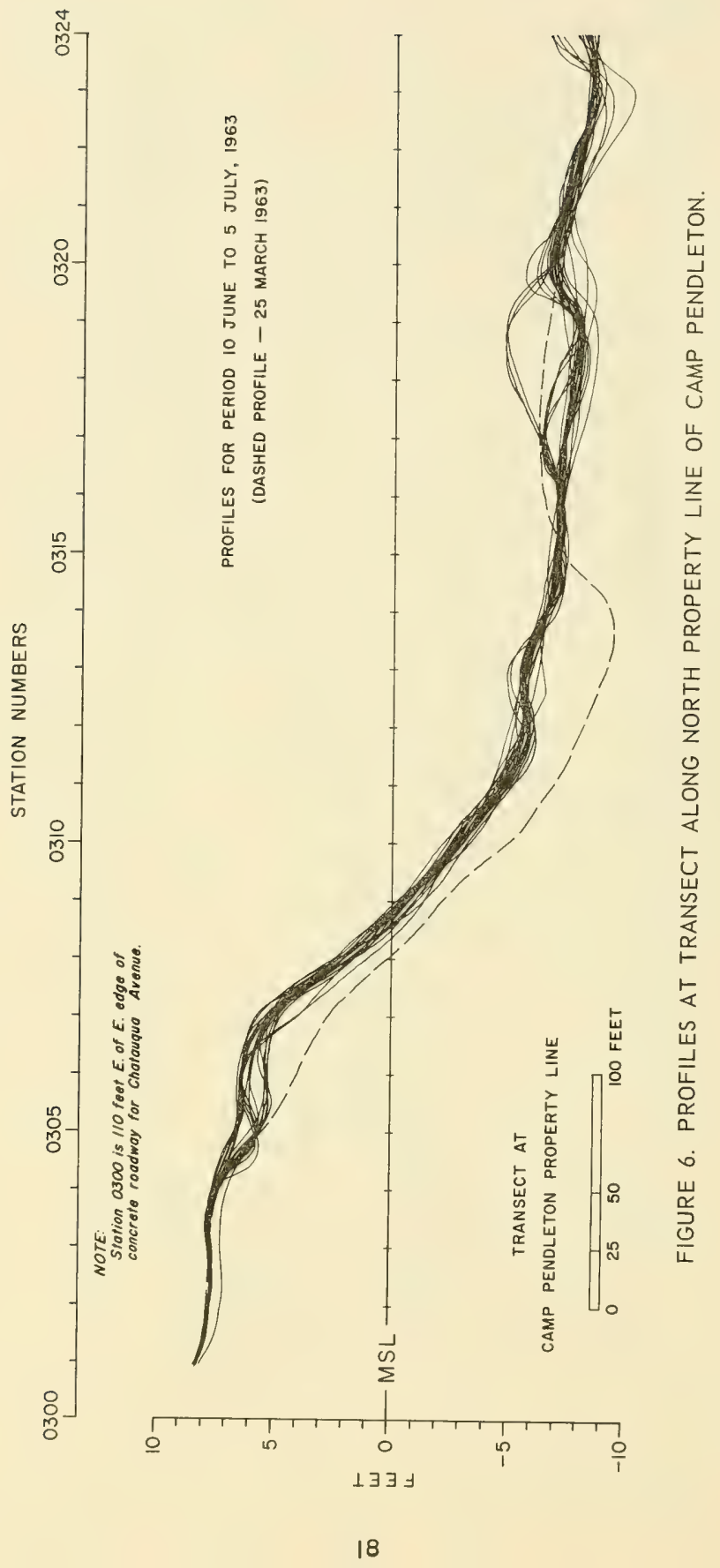




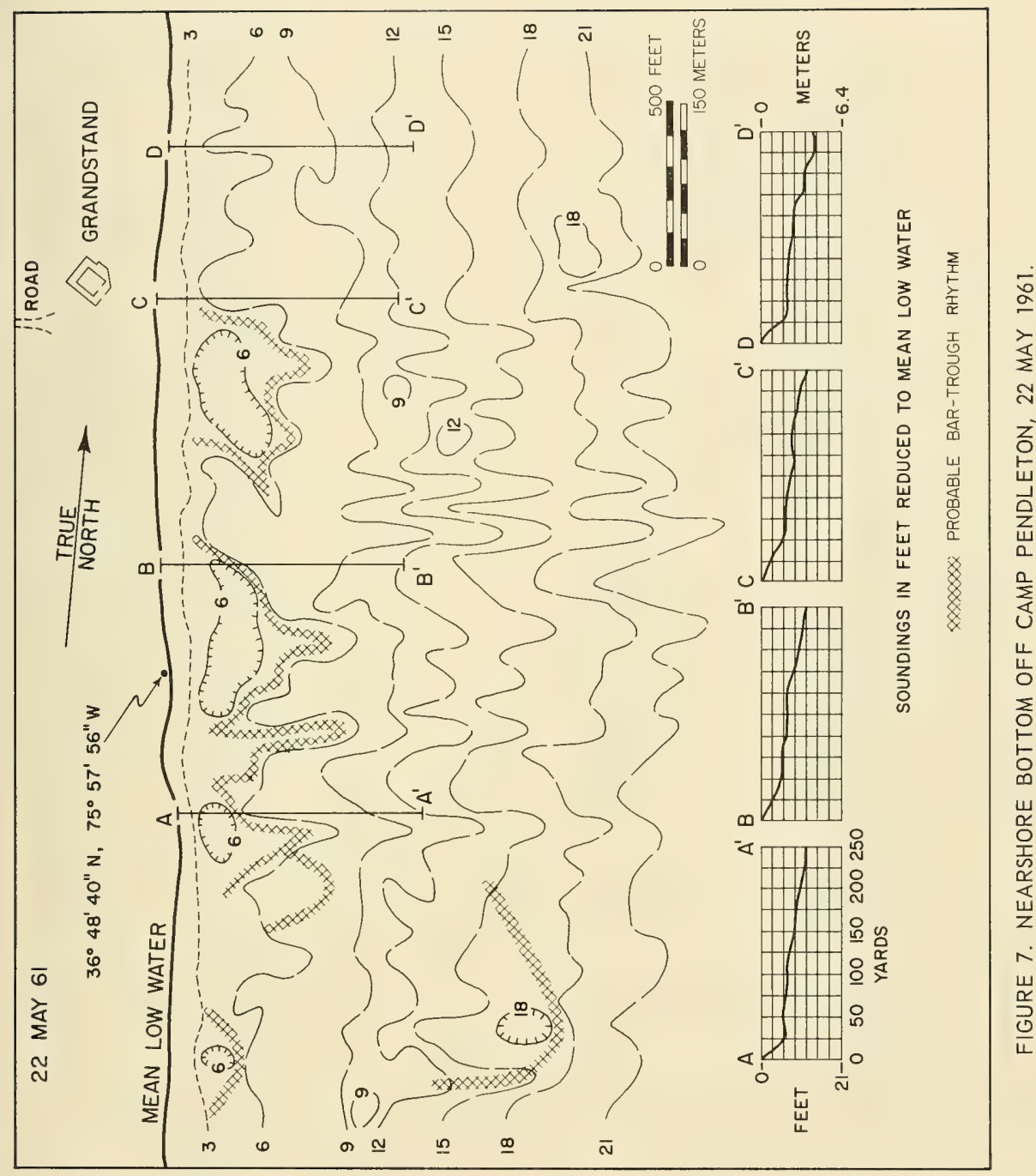




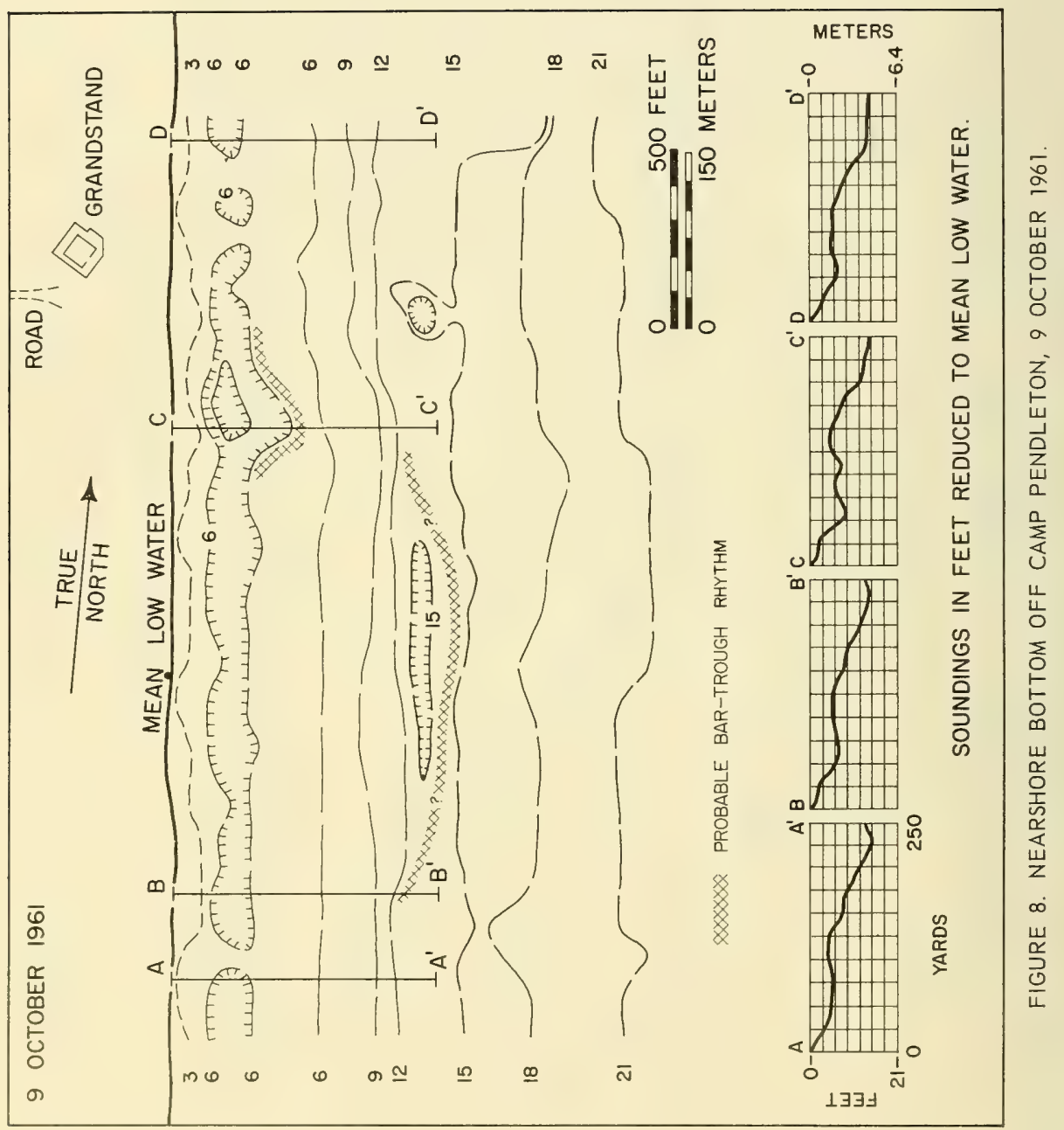




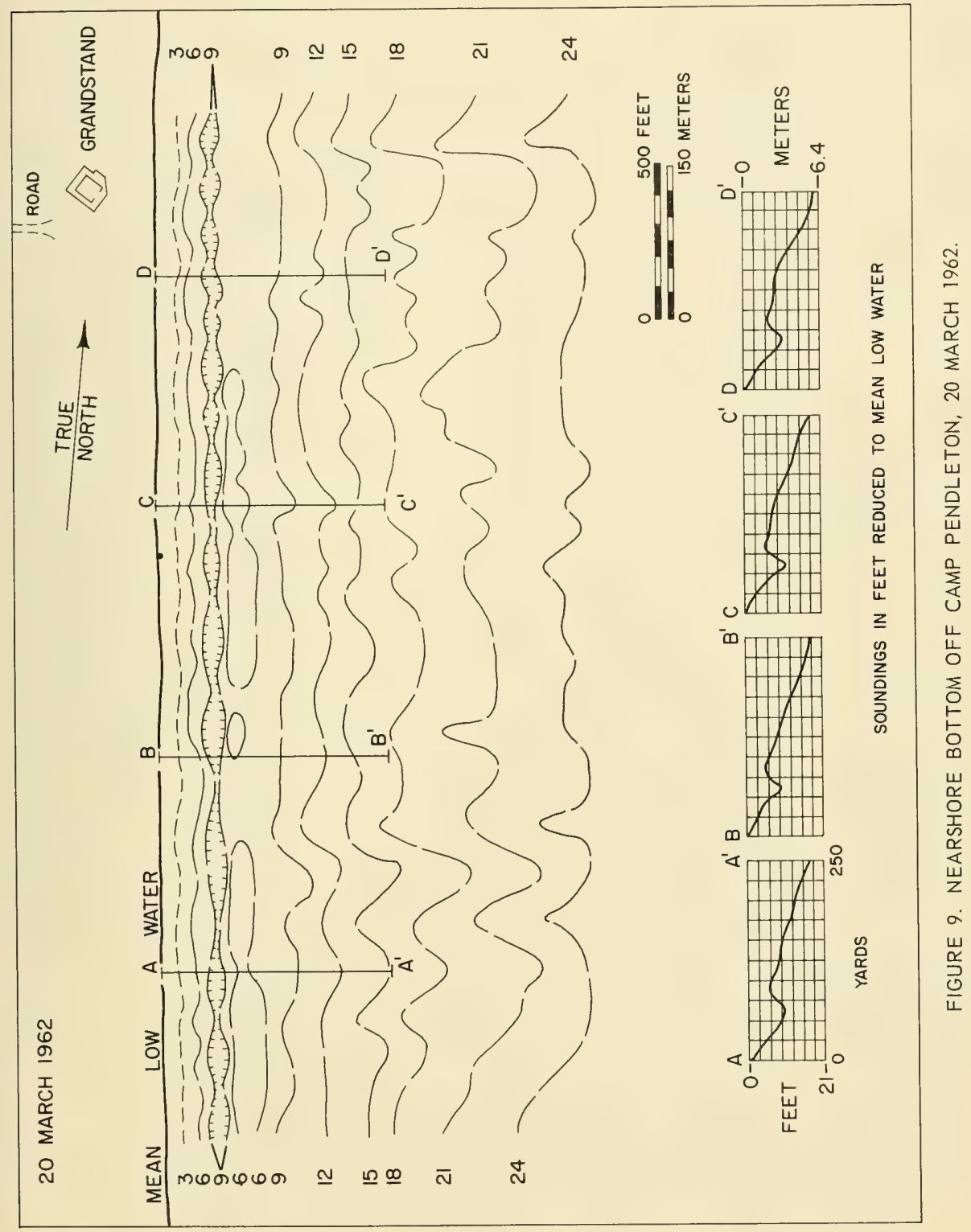




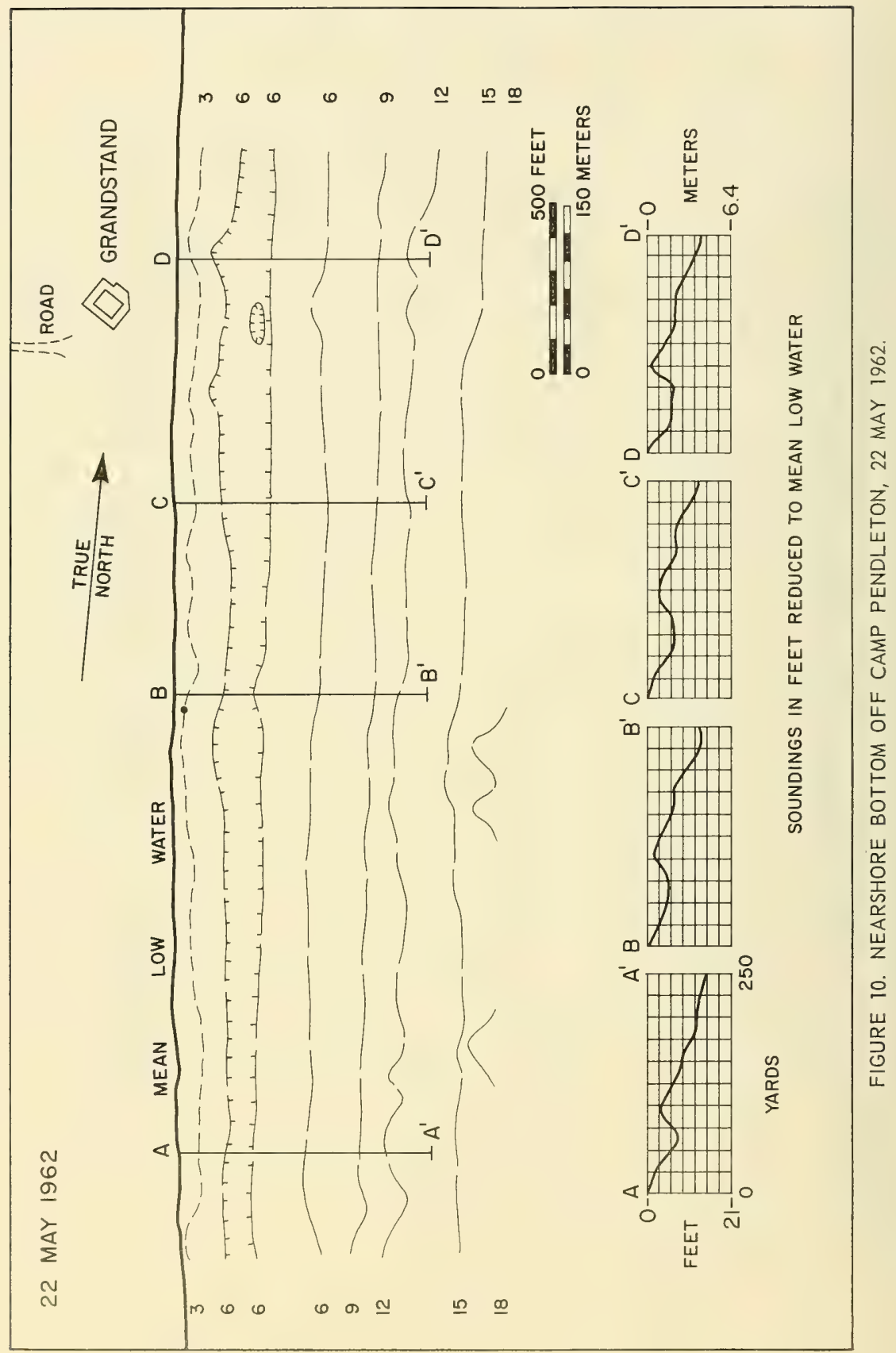




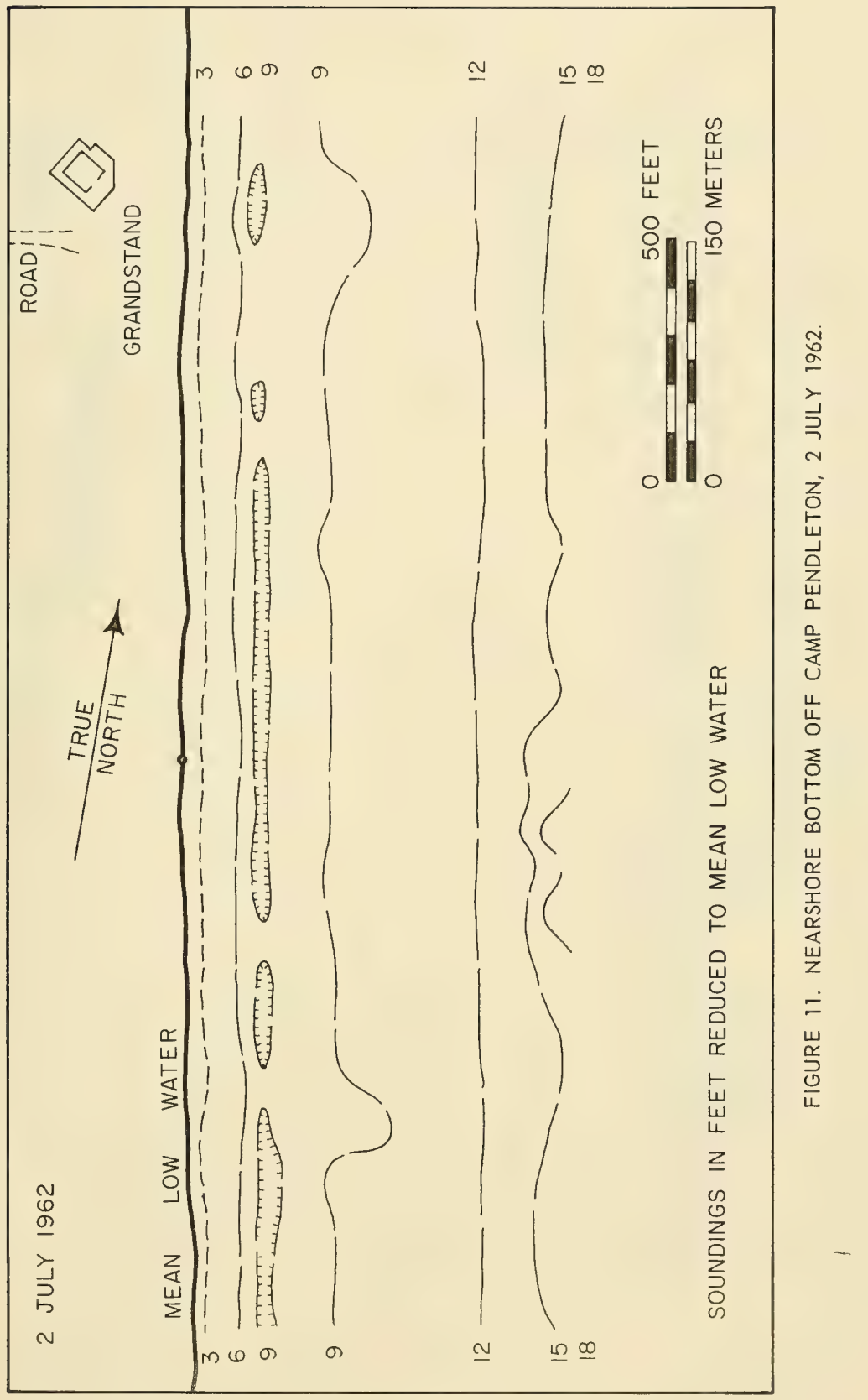




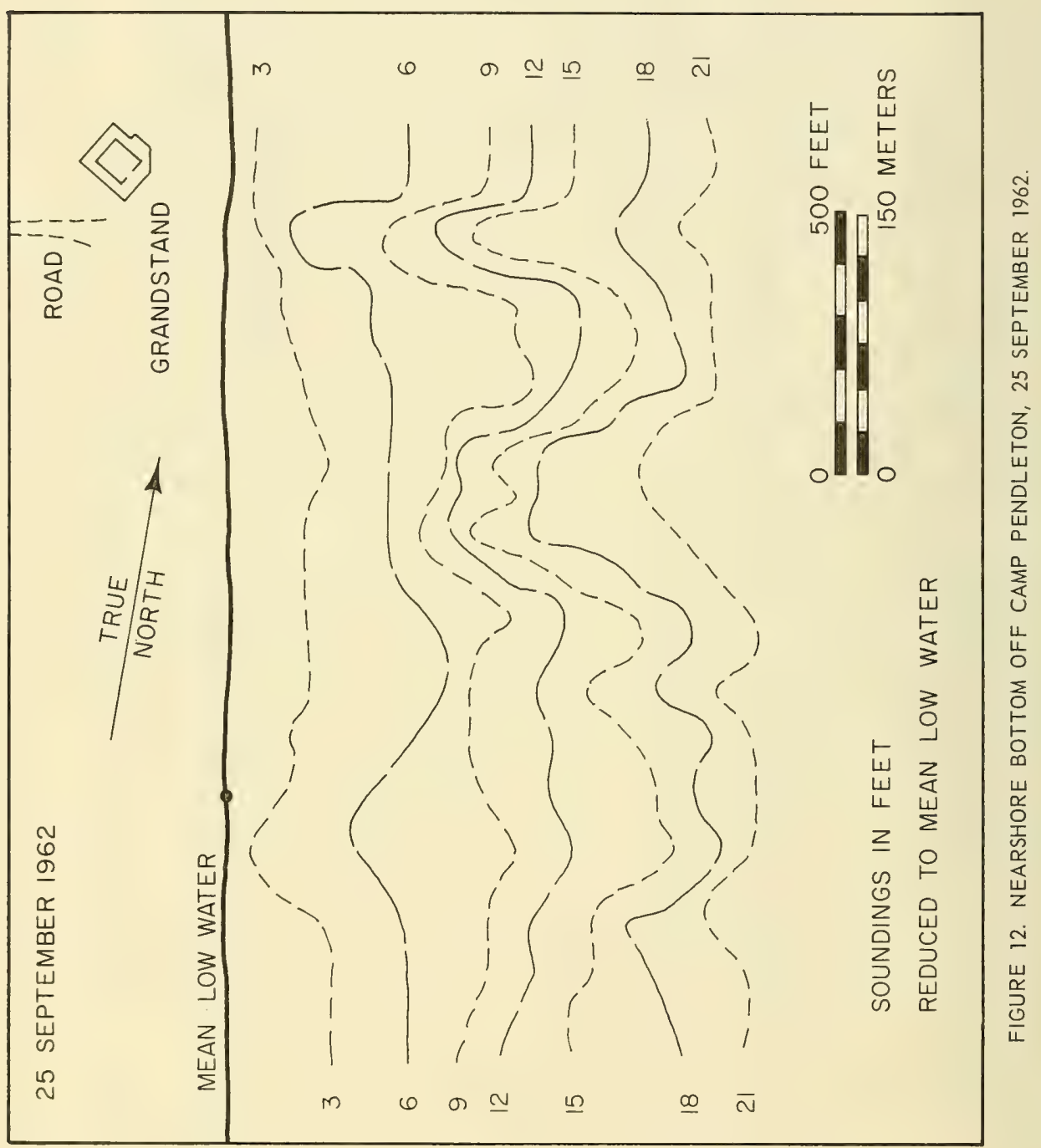




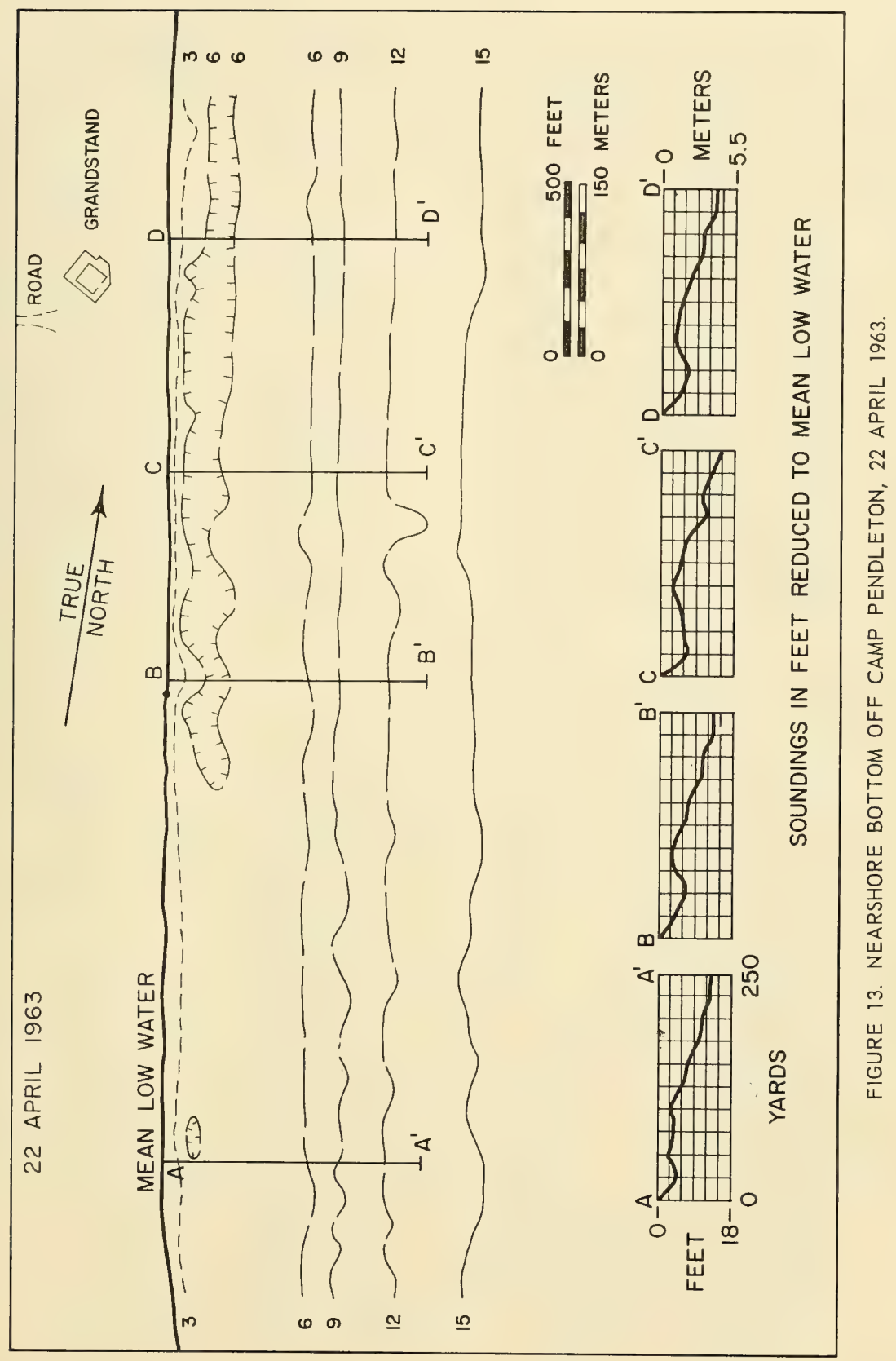





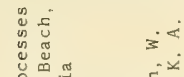

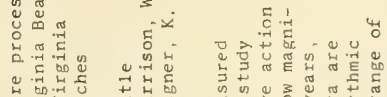

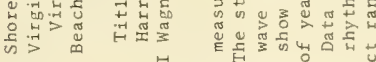

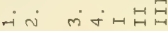

í

s

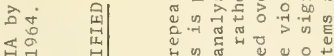

แु

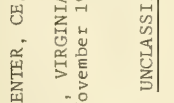

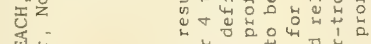

留 息

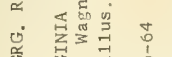

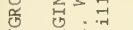

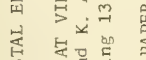

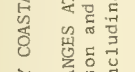

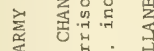

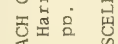

i.

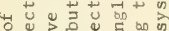

क

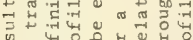

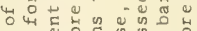

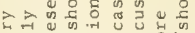

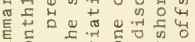

के ह

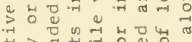

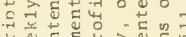

H屯.

苟

न- का का क्ष

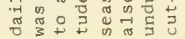

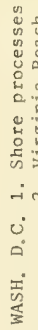

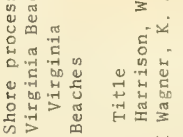

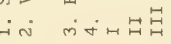

$\frac{5}{3}$

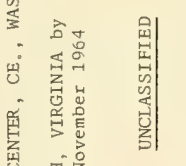

펀 뎐?

这 出艺

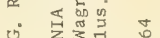

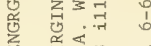

究

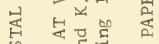

年 थ

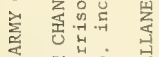

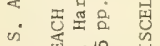

i 齿点 $\sum_{-1}^{-1} \cdot \frac{1}{5}$

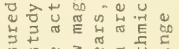

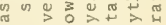

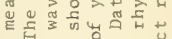

क से

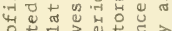

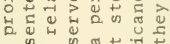

वृ.

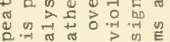

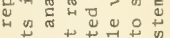

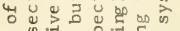

की

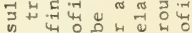

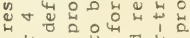

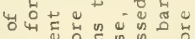

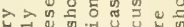

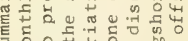

के

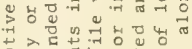

न

us

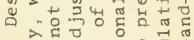

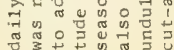

:

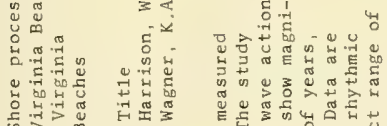

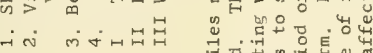

ن

:

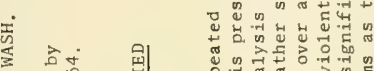

है। 包

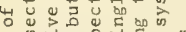

का है

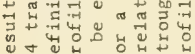

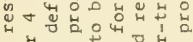

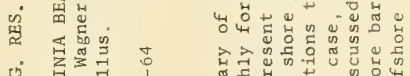

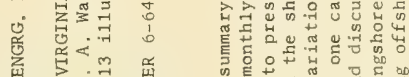

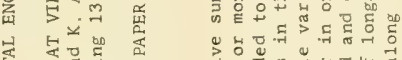

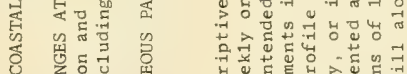

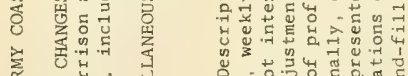

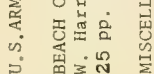

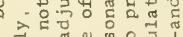

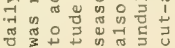

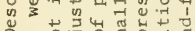

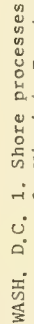

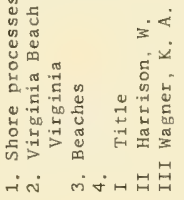

है

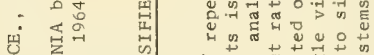

$\therefore$ पू

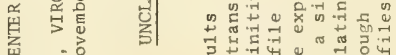

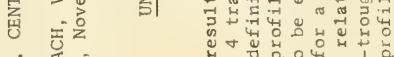

कण मू०

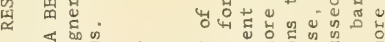

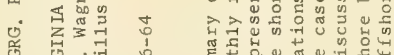

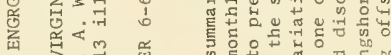

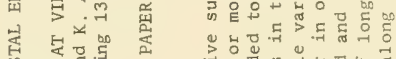

र

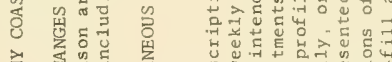

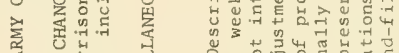

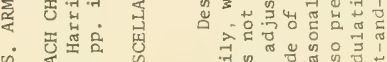

⿰纟. 



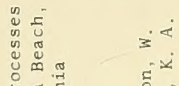

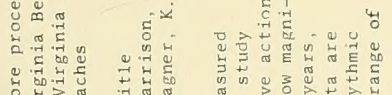
सं की

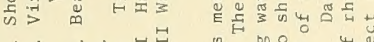

- $\dot{0}$ 的的昆昆

$\dot{0}$

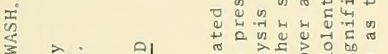

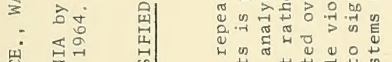

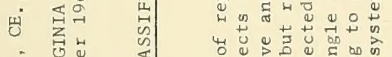

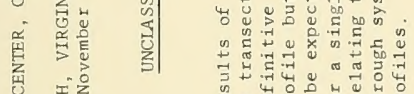

凷 氠员

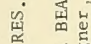

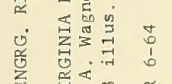

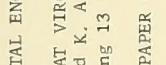

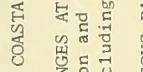

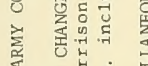

恄蒫员

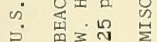

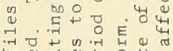

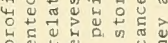

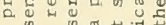

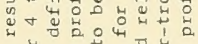

फ

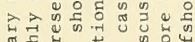

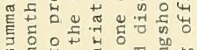

कि

$\rightarrow 0$ एँ

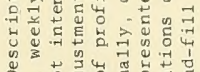

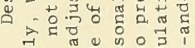

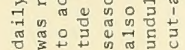

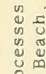

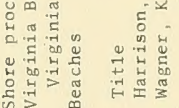

जं लंखंम

ن

$\circ$

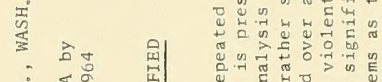

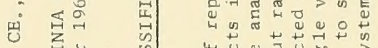

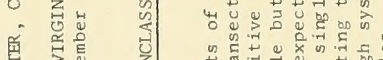

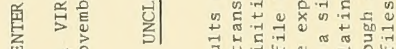

畐 동

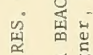

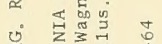

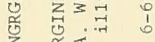

出

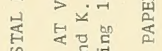

दू का का

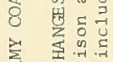

还需

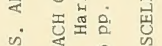

is $3 \mathrm{~m}$

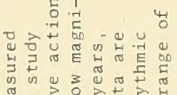

है

离 है

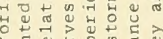

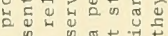

उ山出出

i

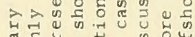

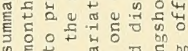

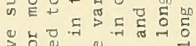

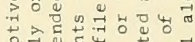

नि

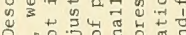

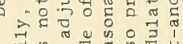

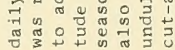

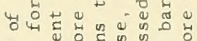

क

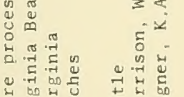

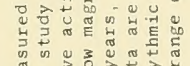

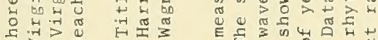

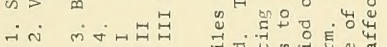

ن.

ङ

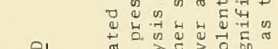

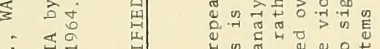

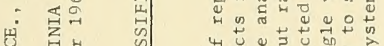

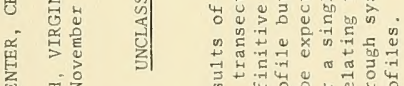

出 दृं ह

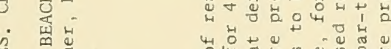

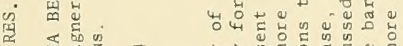

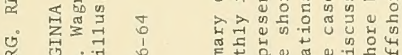

एँ

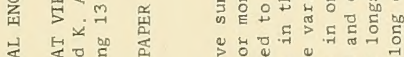

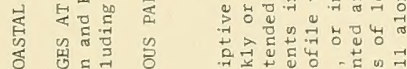

ठ

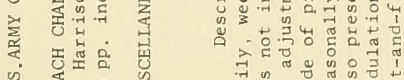

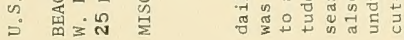

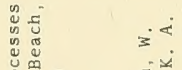

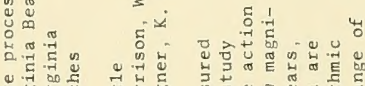

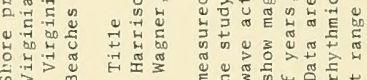

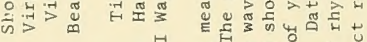

-iं लंष口昆

u.

व

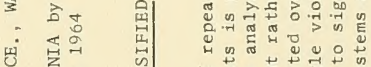

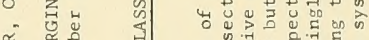

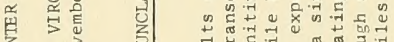

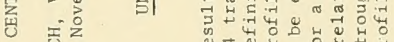

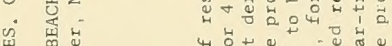

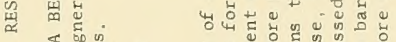

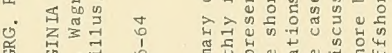

券

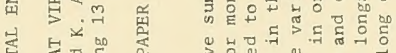

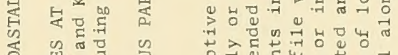

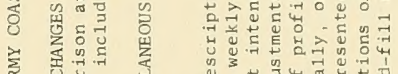

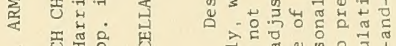

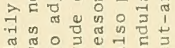



